KEYWORDS

Business enterprises

Industrial enterprises

Corporate financing

Investment

Profit

Corporate debt

Statistical data

Peru

\title{
Profit margins, financing and investment in the Peruvian business sector (1998-2008)
}

\author{
Germán Alarco T.
}

$\mathrm{T}$

his paper develops a model and explains the determinants of profit margins in the Peruvian business sector in the 1998-2008 period. These are established in a fixed-price scenario, with reference to a set of variables such as the price elasticity of demand, the behaviour of possible industry entrants and any regulatory intervention by government. In addition, there is a direct relationship between profit margins and self-financing of investment. Profit margins and profit ratios in the business sector are rising and exceed international norms. The paper also identifies a trend towards lower levels of debt and leverage. It does not reject the hypothesis of linkage between profit margins and investment at the aggregate and sectoral level. The output-to-capital ratio or sales-to-assets ratio is directly linked to profit margins. Most investment is self-financed.

Germán Alarco T.

Principal Research Fellow and Professor at CENTRUM Católica Catholic University of Peru - galarco@pucp.edu.pe 


\section{I}

\section{Introduction}

The economic performance of Peru has been positive over the last decade. The average annual rate of gross domestic product (GDP) growth up to 2009, including the negative effects of the international financial crisis, was 5.3\%. Inflation in the same period was low, averaging $2.5 \%$ a year. A positive trade balance resulted in the build-up of a substantial quantity of international reserves. The public finances were kept in reasonable balance. Both pay and the operating surplus grew in real terms. However, these positive macroeconomic results went together with greater inequality in the functional distribution of income, with the operating surplus gaining at the expense of remuneration as a share of output.

Between 2000 and 2009, remunerations as a share of GDP fell from $24.4 \%$ to $22 \%$, while in the same period the operating surplus rose from $59.1 \%$ to $62.8 \%$ of national output (INEI, 2011). In no other Latin American economy are remunerations such a small share of GDP as in Peru (Lindenboim, 2008). Drawing on long-term statistical information, we find that remunerations fell from just under $40 \%$ of output in the mid-1950s to just over half this level in 2009 (Alarco, 2010b). The labour market factors that might have contributed to this are various, but one important point is that the increasing share of income represented by the operating surplus has been matched by an increase in profit margins in a substantial number of economic activities.

The fact that profit margins are high by international standards is due to the predominance of market structures closer to imperfect competition than more competitive ones with a greater presence of activities that yield substantial economic rents, such as mining and hydrocarbons. In the first group of sectors, these higher margins mean higher domestic prices and lower real remunerations, negatively impacting demand and GDP unless accompanied by higher levels of exports and private-sector investment. Investment as a proportion of GDP rose from $19.6 \%$ in 2000 to $23.7 \%$ in 2009 , having peaked at $29.2 \%$ in 2008 . In other circumstances, the

$\square$ I am grateful for the assistance of Paul Durand Villarroel as general project assistant, to Patricia Del Hierro Carrillo for her suggestions, and to the anonymous referees who commented on this paper. combination of greater inequality and lower exports or lower investment or both would not be a good recipe for economic growth.

This paper will use information from businesses to illustrate the evolution of the operating surplus in the main production sectors and the evolution of profit margins in the Peruvian economy as a whole and the main economic activities between 1998 and 2008. It will employ a post-Keynesian approach to establish the determinants of profit margins, focusing exclusively on fixed-price scenarios. Lastly, it will assess the relationship between profit margins and investment.

Formally, this article contains the following sections. Section II presents the theoretical discussion on profit margins. Section III introduces the basic model relating profit margins to microeconomic and then macroeconomic price-setting. Section IV deals with sources, information processing and the main results of the aggregate information and that furnished by businesses. It analyses the compatibility of the theoretical framework with the statistical information available. Lastly, some final considerations are offered.

This article does not analyse modes of price-setting or profit determination other than the post-Keynesian one. It does not consider the effects on profit margins of competition between firms, or the effects of trade opening. Nor does it evaluate the likely reaction of government competition authorities, which would be expected to act if profit margins became very high. There is no analysis of growth and concentration processes as in Alarco (2010a), or of technical change, corporate behaviour in the presence of higher profit margins, or the appearance of new barriers to entry. Nor does the paper discuss all the problems associated with the fact that the operating surplus in Peru encompasses company earnings, rents and self-employed workers' income, among other elements. ${ }^{1}$

\footnotetext{
1 The Central Reserve Bank of Peru (BCRP) published the details of the operating surplus from 1960 to the mid-1970s. Subsequently, the National Institute of Statistics and Informatics (INEI) integrated all the earlier concepts, but currently only presents homogeneous series from 1991 onward.
} 


\section{II}

\section{Determinants of profit margins}

Kalecki (1956, pp. 11-12) focuses on products determined mainly by changes in production costs, as opposed to those explained by changes in demand (especially agricultural products). In the first group of products, supply is elastic because there is spare installed capacity. It is also assumed that costs per unit produced do not alter when production rises. Higher demand is responded to by a rising volume of output, without any tendency for prices to change. The other component dealt with in passing by Kalecki is the presence of uncertainty in the pricing process, so that firms seek to maximize profits but do so in an imprecise way.

Under these conditions, any firm's prices reflect its prime costs (cost of raw materials and payment of direct wages) and its degree of monopoly, which covers general costs (these being more or less fixed over time) and includes profits. The same author identifies at least four determinants of variations in the degree of monopoly: processes of concentration, sales promotion through advertising, protection of profits in depressed periods and the activity of labour unions, in some degree preventing monopoly power from increasing.

The more that concentration in an industry leads to the formation of larger firms, the greater the degree of monopoly will be. Prices will be higher in relation to prime costs when the structure of the market is less competitive. Likewise, the existence of more or less formal cartel-type agreements between producers will tend to increase the degree of monopoly. In another area, a rise in general costs may increase the degree of monopoly, particularly at times of recession and still more so when there is a tacit agreement between firms in the same industry to protect profits. Lastly, greater union action will prevent the degree of monopoly from increasing. If firms tend to increase their prices in the wake of wage adjustments, unions will apply renewed pressure, raising costs (Kalecki, 1956, pp. 17-19).

These markets subsequently came to be called "fixed-price" markets and monopoly was replaced by mark-up, which would likewise be applied to unit production costs (labour and raw materials). Ocampo (1988, p. 20) argues that theoretical analysis has led to the identification of two fundamental determinants of profit margins: competition conditions and corporate demand for investment funding. For Sylos Labini (1966), conversely, profit margins are set with the goal of limiting the entry of new firms into the market. Markets contain firms of different sizes, large, medium-sized and small, with the largest firms generally taking the lead in pricesetting but potentially being affected by the reactions and performance of smaller ones.

Sylos Labini (1969) argues that if the firm or firms with pricing power wish to prevent the entry of new firms of a particular type, they must undercut the price these firms need to charge to obtain the minimum rate of profit. If the firms with pricing power wish to force out firms already operating, they need to set the price at a level that undercuts the direct costs of the firms they are seeking to force out.

Steindl (1988) links firms' profit margins to their investment funding requirements. Firms with higher profit margins accumulate funds internally, and the greater their differential advantage, the more they accumulate. For Steindl, an increase in an industry's profit margin will lead to a rise in the internal accumulation rate, and this in turn will result in an increase in production capacity. If this increase is greater than the growth in the industry's sales, it will lead to greater concentration benefiting the firm with the highest profit margin and level of accumulation. Ocampo (1988) comments that the existence of an oligopolistic or monopolistic context, with high entry barriers, makes the appearance of new firms in the sector unlikely, within certain limits.

Eichner (1988) then notes that profit margins depend on the demand for and supply of additional investment funding on the part of the firm or group of firms with pricing power in their industry. Firms can increase their margin over costs to obtain more internally generated funding, although they are constrained by: (i) the substitution effect, as higher margins make customers more likely to opt for a substitute product, (ii) the entry factor, with new firms overcoming the barriers to entry in the industry, and (iii) significant government intervention in response to increasing evidence of uncompetitive practices in the marketplace.

Eichner (1988, pp. 213-217) argues that the reduction in cash flow resulting from factors (i) and (ii) above is analogous to the reduction in financial flows resulting from the higher interest that would be payable on external financing. There is an implied rate of interest on additional funding generated internally. An increase in the margin over costs will increase the 
implied cost of additional investment funding. As the margin increases, the substitution effect and the entry factor would be expected to grow disproportionately, so that the implied interest rate would also rise at an increasing pace. When demand for investment is greater than can be financed internally whilst avoiding the substitution effect or the entry factor, use will be made of supplementary external financing.

Along the same lines, Wood (1988) argues that firms have to cope with two frontiers: a finance frontier and an opportunity frontier. The first of these concerns the relationship between a firm's internal funding and its investment needs. The opportunity frontier, meanwhile, expresses the ratio between the profit margin, sales and the marginal investment-to-output ratio. As a firm's profit margin rises, it generates more resources for growth but has to contend with a smaller increase in sales.

Harcourt and Kenyon (1988) argue that a firm has a twofold objective in setting its profit margin. First, pricing needs to be compatible with expectations of demand for what it produces. Second, it needs to be high enough to generate retained earnings sufficient to finance the firm's investment plans. When firms succeed in setting sufficient retained earnings margins for them to expand capacity in line with demand growth in the market, the conditions are created for investment to maintain capacity growth that keeps up with demand in the context of a stable market share (Harcourt and Kenyon, 1988).

In this fixed-price scenario, neither temporary changes in variable costs nor temporary changes in product demand directly influence the price of the product. What happens is that the level of output adjusts to the level of demand in accordance with the business cycle. As Harcourt and Kenyon (1988, pp. 233 and 238) note, however, as demand and cost conditions change, the firm will realize that its plant capacity is inadequate and new investment is required. In these circumstances, the firm will decide whether the flow of investment funding is appropriate to the current price level. If not, the price and investment decision-making process will have to be reopened.

Vargas (2007, p. 192) revisits the proposals of Eichner and Kregel and argues that, for post-Keynesians, the generation of internal funding to finance investment is the rule, while external financing is the exception when the implied interest rate is distinguished from the market interest rate. If the implied rate is lower than the market rate, the firm will increase its financing by raising prices. If not, the firm will prefer to finance itself through the money market. However, the authors conclude that nobody could calculate the point at which the demand for and supply of internal funding intercept.

For Vargas (2007, pp. 177 and 202), both the level of and changes in profit margins depend on a set of variables such as the substitution effect ${ }^{2}$ (price elasticity of demand), the behaviour and reaction of any entrants into the industry, any government intervention, the growth rate of the industry and the increase in the output-tocapital ratio relative to other industries. These last two variables are the counterpart of the firm's investment decisions. In this regard, the main decisions for any firm's managers are: (i) the targeted rate of return on investment, (ii) the new investment projects to be included in the annual capital budget, (iii) the profit margin required for their investment plans, (iv) the annual increase in salaries, wages and dividends, and (v) changes in the company's debt level.

\footnotetext{
${ }^{2}$ According to neoclassical microeconomics, the profit margin relative to price is equivalent to the inverse of the price elasticity of demand (Urzúa, 2009, p. 94) $(P-c m g) / p=1 / \eta$.
}

\section{III}

\section{The basic model}

The explanatory factors and determinants of profit margins are an issue that can be addressed in two spheres: at the microeconomic level and at the macroeconomic level. As noted earlier, a post-Keynesian approach which assumes a fixed-price scenario is followed in both cases for simplicity's sake. Under this condition, the identity of total revenue $(T R)$, equivalent to prices $(P)$ by quantities produced $(X)$ in equation $(1)$, becomes total expenditure (E) by one, plus the profit margin (z) of equation (2). Equation (3) then incorporates the traditional financial ratio relating to total sales turnover, which expresses the proportion of sales to the value of total assets $(A)$ 
in any firm, this being a proxy for the output-to-capital ratio. Likewise, equation (5) defines both total assets as the sum of liabilities $(L)$, and equity: capital or partners' investments $(C)$. Likewise, the proportion of liabilities to equity must be as determined by $k$ in equation (6).

$$
\begin{gathered}
T R=P X \\
T R=E(1+z) \\
R=\frac{I T}{A} \\
\frac{R A}{E}=(1+z) \\
A=L+C \\
\frac{P}{C}=k \\
A=C(1+k)
\end{gathered}
$$

When equation (6) is substituted into (5), we get equation (7), which is then substituted into (4) to determine equation (8). This last equation shows that the profit margin of a firm, a sector or all firms in any economy is directly proportional to the turnover of total assets, partners' investments (equity) and debt levels (liabilities), and inversely related to total expenditure. A higher sales-to-assets ratio would be matched by higher profit levels. Underlying the decision to raise the profit margin, again, is an explicit policy to self-finance productive investment. Increased third-party financing would be on a scale such as to maintain the proportions determined by the market to be acceptable.

$$
\frac{R C(1+k)}{E}=(1+z)
$$

At the aggregate level, the assumptions used, which are also those of Taylor (1986), have been a simple economy with a single production sector; two social groups, namely wage earners and recipients of profits (owners of the means of production); and a single production input, namely labour. Total expenditure $(E)$ is the product of average remuneration $(w)$ and labour content per unit of output $(l X)$, as indicated by equation
(9). When these are substituted into equation (8), we get an expression equivalent to the previous one, where the profit margin $z$ rises as a result of the components set out in equation (8) and because of the reduction in average wages or in labour content per unit of output.

$$
\begin{gathered}
E=w l X \\
\frac{R C(1+k)}{w l X}=(1+z) \\
{\left[\left(\frac{R C(1+k)}{w l X}\right)-1\right] 100=z}
\end{gathered}
$$

Equation (12) is equivalent to (2) if labour is treated as the only production input. Equation (13) determines the level of real production on the basis of consumption and investment. For the purposes of this study, there is no government and no external sector. Equations (14) and (15) deal with nominal demand for consumer goods from the owners of the means of production and from wage earners. They depend on the respective propensity of these to consume $\left(\gamma_{i}\right)$, on the mass of remunerations $(w l X)$ and, in the case of the owners of the means of production, on the profit margin $z$. Real private-sector consumption as expressed in equation (16) is equivalent to the sum of nominal demand for consumer goods deflated by the price level. Substituting this last equation into (12), we get the reduced form of real output observed in equation (18).

$$
\begin{gathered}
P=w l(1+z) \\
X=C+I \\
D_{z}=\gamma_{z} z w l X \\
D_{w}=\gamma_{w} w l X \\
C=\frac{D_{z}+D_{w}}{P} \\
X=\frac{\gamma_{z} z w l X+\gamma_{w} w l X}{P}+I
\end{gathered}
$$

Real output is determined by multiplying the autonomous spending component, which in this case would only be nominal private-sector investment, by 
the spending multiplier, which incorporates the different propensities of owners and wage earners, the profit margin and the level of real remunerations. If private-sector investment is greater, output will be higher. Similarly, if there is an increase in the profit margin, a corollary of which is a reduction in the output share accruing to labour, then income will become more concentrated in favour of the owners of the means of production, to the detriment of wage earners. Then, the lesser propensity to consume of owners as compared to wage earners reduces the spending multiplier and output tends to grow by less. One effect that might counteract this fall would be higher investment, owing to the positive (direct) effect this has on demand, or a rise in exports, if an open economy model is worked with.

$$
X=\frac{I P}{1-\gamma_{z} \frac{z}{1+z}-\gamma_{w} l \frac{w}{p}}
$$

Equation (19) presents the equality between saving and investment in nominal terms. In aggregate terms, total saving is broken down between that carried out by the owners of the means of production and that carried out by wage earners. What is considered in the first case is the propensity to save $\left(S_{i}=1-\gamma_{1} i\right)$ multiplied by the profit margin $z$ and the mass of remunerations that is the only production input. In the second case, it is the saving carried out by wage earners that is considered.

$$
\begin{gathered}
A=I P \\
S_{z} z w l X+S_{w} w l X=(1+z) w l I \\
z=\frac{\frac{I}{X}-S_{w}}{S_{z}-\frac{I}{X}}
\end{gathered}
$$

Equation (21) explains the profit margin of the economy by the investment-to-output ratio and propensity to save. As Taylor (1986) comments, $z$ will be positive as long as there is a positive difference between the respective propensities to save of owners and wage earners. When $S_{z}>S_{w}$, the share $\frac{I}{X}$ of needs to have an intermediate value for there to be macroeconomic equilibrium. The proportion between the profit margin and the investment-to-output ratio must be positive, as discussed in the microeconomic analysis.

\section{IV}

\section{Information processing and results}

Before beginning the processing and analysis of information from firms, we should consider table 1. Based on all the information available from INEI (2011), this shows that the operating surplus had a clear upward tendency between 1991 and 2009, rising from $52.7 \%$ of GDP to close to $62.8 \%$. A review of this series reveals that the largest increases took place between 1991 and 1993, the time of the adjustment and stabilization programme in the early part of the Fujimori Government. The other jump was between 2003 and 2008, and was associated both with the increased output share of mining and with higher international prices for the sector's export products.

Manufacturing now accounts for a little under $13 \%$ of the operating surplus generated in the Peruvian economy, this share having peaked at over $16 \%$ at the beginning of the period under analysis. The commerce and services sector now makes a smaller contribution to the surplus than formerly. The contribution of the agriculture, hunting, forestry and fishing sector to the total surplus has also been declining. Conversely, the contribution of mining and electricity, water and construction to the surplus more than doubled between 1991 and 2009. This statistical information does not convey the increased contributions of the transport and communication sector in relation to the financial sector, as these are part of the commerce and services sector. Here, there has been a drop in the contributions of commerce, restaurants and hotels, and other services.

Profit margins are assessed from information provided by businesses, specifically an annual report on the performance of the country's 10,000 leading firms. Unlike the official information, this presents records of total sales or revenues, total assets, liabilities, equity and net after-tax earnings, which are useful for the present analysis. This study has considered all the 
TABLE 1

Peru: the operating surplus as a share of GDP and sectoral contributions (Percentages of GDP and of the total)

\begin{tabular}{|c|c|c|c|c|c|c|}
\hline \multirow[b]{2}{*}{ Year } & \multirow{2}{*}{$\begin{array}{l}\text { Operating surplus } \\
\text { (percentage of GDP) }\end{array}$} & \multicolumn{5}{|c|}{ Production sector (percentage of the total) } \\
\hline & & $\begin{array}{l}\text { Agriculture, hunting, } \\
\text { forestry and fishing }\end{array}$ & Mining & Manufacturing & $\begin{array}{l}\text { Electricity, water } \\
\text { and construction }\end{array}$ & $\begin{array}{c}\text { Commerce and } \\
\text { services }\end{array}$ \\
\hline 1991 & 52.71 & 7.78 & 4.09 & 16.14 & 4.75 & 67.24 \\
\hline 1992 & 56.40 & 7.73 & 4.43 & 16.13 & 4.80 & 66.91 \\
\hline 1993 & 58.40 & 8.20 & 4.62 & 16.17 & 5.95 & 65.06 \\
\hline 1994 & 58.13 & 8.32 & 4.67 & 15.98 & 7.47 & 63.56 \\
\hline 1995 & 57.57 & 7.91 & 4.51 & 15.10 & 8.29 & 64.19 \\
\hline 1996 & 57.98 & 8.33 & 4.34 & 14.91 & 8.12 & 64.30 \\
\hline 1997 & 58.85 & 7.83 & 4.30 & 14.84 & 8.62 & 64.41 \\
\hline 1998 & 58.25 & 8.12 & 3.96 & 14.24 & 8.67 & 65.00 \\
\hline 1999 & 58.55 & 7.97 & 4.90 & 13.97 & 8.03 & 65.14 \\
\hline 2000 & 59.10 & 7.76 & 5.22 & 14.43 & 7.64 & 64.96 \\
\hline 2001 & 58.32 & 7.56 & 4.92 & 14.66 & 7.51 & 65.35 \\
\hline 2002 & 58.75 & 7.21 & 5.49 & 14.50 & 7.60 & 65.19 \\
\hline 2003 & 58.71 & 6.98 & 6.06 & 14.22 & 7.60 & 65.15 \\
\hline 2004 & 59.62 & 6.63 & 7.68 & 14.87 & 7.47 & 63.35 \\
\hline 2005 & 60.36 & 6.56 & 8.84 & 14.93 & 7.49 & 62.17 \\
\hline 2006 & 61.92 & 6.35 & 11.66 & 14.63 & 7.54 & 59.81 \\
\hline 2007 & 62.39 & 6.40 & 11.42 & 14.58 & 7.85 & 59.75 \\
\hline 2008 & 63.00 & 6.60 & 10.40 & 14.55 & 8.12 & 60.33 \\
\hline 2009 & 62.77 & 6.76 & 9.77 & 12.97 & 8.79 & 61.71 \\
\hline
\end{tabular}

Source: prepared by the author on the basis of National Institute of Statistics and Informatics (INEI), "Sistema de información económica", 2010 [online] http://www.inei.gob.pe/web/aplicaciones/siemweb/index.asp?id=003.

GDP: gross domestic product.

electronic information available in Peru: The Top 10,000 Companies for the period from 1998 to 2008.

Peru: The Top 10,000 Companies started in 2001, although before this report existed the same firm, Peru Top Publications, had issued an earlier one since 1985 giving the main details from the financial statements of the top 200, 500 and 2,000 firms in Peru. The report is well regarded in the country's business sector, whose members are the main direct source of its information, this being supplemented by public information from the Business and Securities National Supervisory Commission (CONASEV) and other private-sector sources.

Table 2 shows the representativeness of the sample in respect of two variables: sales as a proportion of GDP and the share of gross profit in the operating surplus reported by INEI. This reveals that there is no problem at all where sales are concerned. ${ }^{3}$ However, it becomes less representative in 2008 as regards companies' gross profits. In the last year, firms tended not to report or to omit information on after-tax profits, as these

\footnotetext{
${ }^{3}$ Unfortunately, the database does not provide the production data that would be most helpful in applying a production to GDP ratio.
}

were trending upward and had risen from the levels of earlier years. ${ }^{4}$

Table 3 gives information on the number of firms to be included in the year-by-year analysis. This excludes firms which do not present full information on all the variables mentioned earlier. The low coverage in 2000 , 2003 and 2008 is striking. ${ }^{5}$ In the case of 2004 , there was a negative overall earnings balance that is explained by the results of the Pensions Normalization Office (ONP) ${ }^{6}$ and the Police Military Pensions Fund. The decision was also taken to exclude these from the database for all the years in the period.

Figure 1 shows the results of applying the HerfindahlHirschman Index (HHI) for all variables of the firms in the sample. The HHI determines the level of market concentration and is defined as the sum of squares of

\footnotetext{
4 It must not be forgotten that firms provide financial information voluntarily and have no legal obligation to do so.

5 This affects the representativeness of the database, but there is no way around it. This is not a serious problem, in any case, as removing firms does not create a particular bias preventing the information from businesses being processed as a sample.

6 The body responsible for the public pension system.
} 
TABLE 2

Representativeness of the sample in Peru: The Top 10,000 Companies in relation to GDP and the operating surplus, 1998-2008

(Percentages)

\begin{tabular}{lccc}
\hline Year & Number of firms $^{\mathrm{a}}$ & Sales-to-GDP ratio & Gross profits \\
\hline 1998 & 4951 & 73.96 & 1.67 \\
1999 & 3249 & 72.71 & 8.35 \\
2000 & 2271 & 61.34 & 3.15 \\
2001 & 2391 & 55.07 & 4.50 \\
2002 & 10000 & 98.00 & 2.81 \\
2003 & 9354 & 93.84 & 4.26 \\
2004 & 2375 & 52.99 & 9.60 \\
2005 & 2475 & 63.69 & 21.87 \\
2006 & 7104 & 102.97 & 21.27 \\
2007 & 8477 & 100.96 & 4.14 \\
2008 & 7946 & 102.87 & \\
\hline
\end{tabular}

Source: prepared by the author on the basis of data from the National Institute of Statistics and Informatics (INEI) and from Peru: The Top 10,000 Companies, various years.

a Number of firms that at least report sales.

GDP: gross domestic product.

TABLE 3

Peru: The Top 10,000 Companies: adjusted database with full information, ${ }^{\text {a } 1998-2008}$

\begin{tabular}{clc}
\hline Year of data processed & \multicolumn{1}{c}{ Source } & Number of firms in the year's sample \\
\hline 1998 & Peru: The Top 10,000 2001 & 2962 \\
1999 & Peru: The Top 10,000 2001 & 500 \\
2000 & Peru: The Top 10,000 2002 & 149 \\
2001 & Peru: The Top 10,000 2003 & 765 \\
2002 & Peru: The Top 10,000 2004 & 557 \\
2003 & Peru: The Top 10,000 2005 & 677 \\
2004 & Peru: The Top 10,000 2006 & 910 \\
2005 & Peru: The Top 10,000 2007 & 165 \\
2006 & Peru: The Top 10,000 2009 068 \\
2008 & Peru: The Top 10,000 2009 & 496
\end{tabular}

Source: prepared by the author on the basis of data from the National Institute of Statistics and Informatics (INEI) and from Peru: The Top 10,000 Companies, various years.

a Firms that did not report any sales, assets, liabilities, equity or net profits were removed from the database.

the market shares of each firm in the industry. ${ }^{7}$ The use of squares is justified because greater weighting is being given to firms with a larger market share, so that the index measures the relative size of firms depending on whether there are just a few firms with high market

$7 \mathrm{IHH}=\sum_{i: 1}^{n} S_{i}^{2}$, where $S_{i}$ is each firm's share of the market concerned. The maximum value of the HHI is 10,000 when a firm has $100 \%$ of the market. According to the United States Department of Justice (http:// www.usdoj.gov/atr/hmerger/11247.htm), markets can be classed as unconcentrated (if $\mathrm{HHI}<1,000$ ), moderately concentrated (if 1,000 $<\mathrm{HHI}<1,800$ ) or highly concentrated (if $\mathrm{HHI}>1,800$ ). shares (which would give an index with a high value) or numerous small firms with small market shares, whereupon we would have a low index value. Figure 1 reveals a tendency towards greater concentration of aftertax profits and of liabilities in 2005, after which there is a gradual decline. A restricted group of firms accounts for the bulk of profits and liabilities. Concentration levels are low in the case of sales, assets and equity in an analysis of a general type.

Figure 2 shows the sales, assets, liabilities and equity shares of the top 10 and 100 firms in the sample. The contribution of these subgroups is important for the 
FIGURE 1

Herfindahl-Hirschman index $(\mathrm{HHI})$ for sales, assets, liabilities, equity and profits according to Peru: The Top 10,000 Companies, 1998-2008

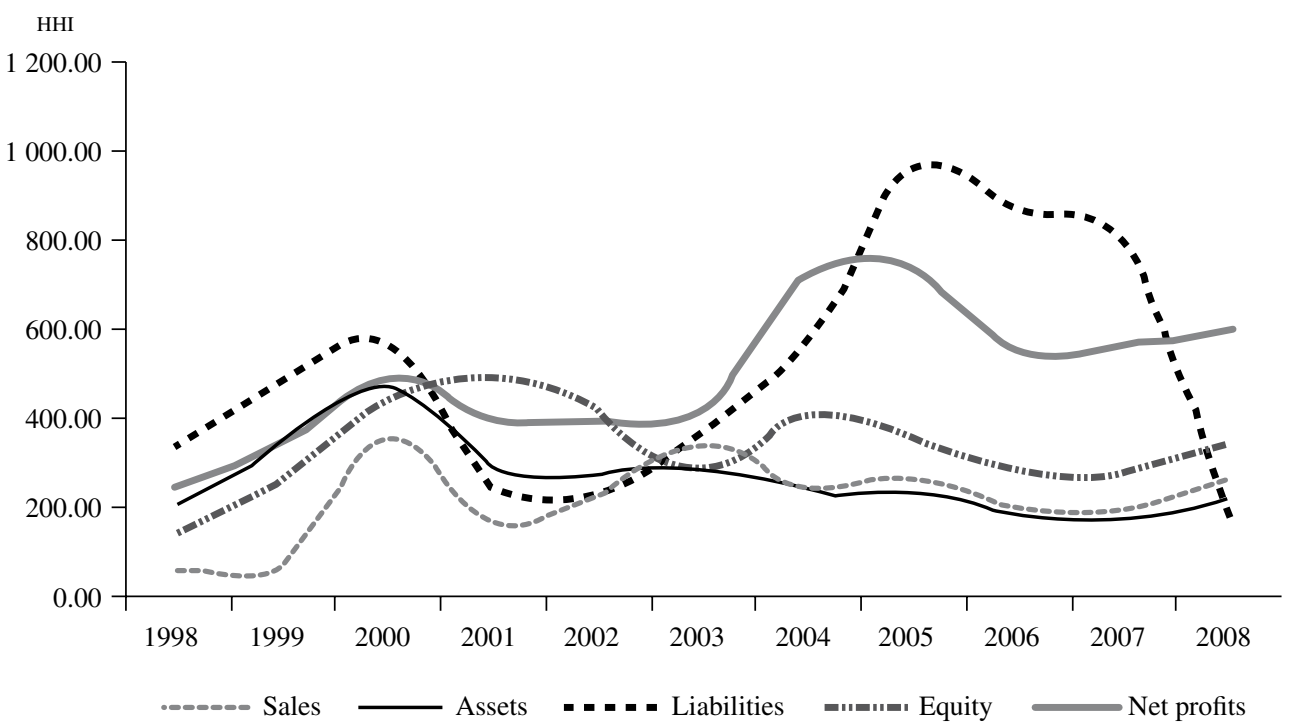

Source: prepared by the author on the basis of data from Peru: The Top 10,000 Companies.

FIGURE 2

Contribution of the top 100 and 10 firms $^{a}$ to sales, assets, liabilities and equity according to Peru: The Top 10,000 Companies, 1998-2008

(Percentages)

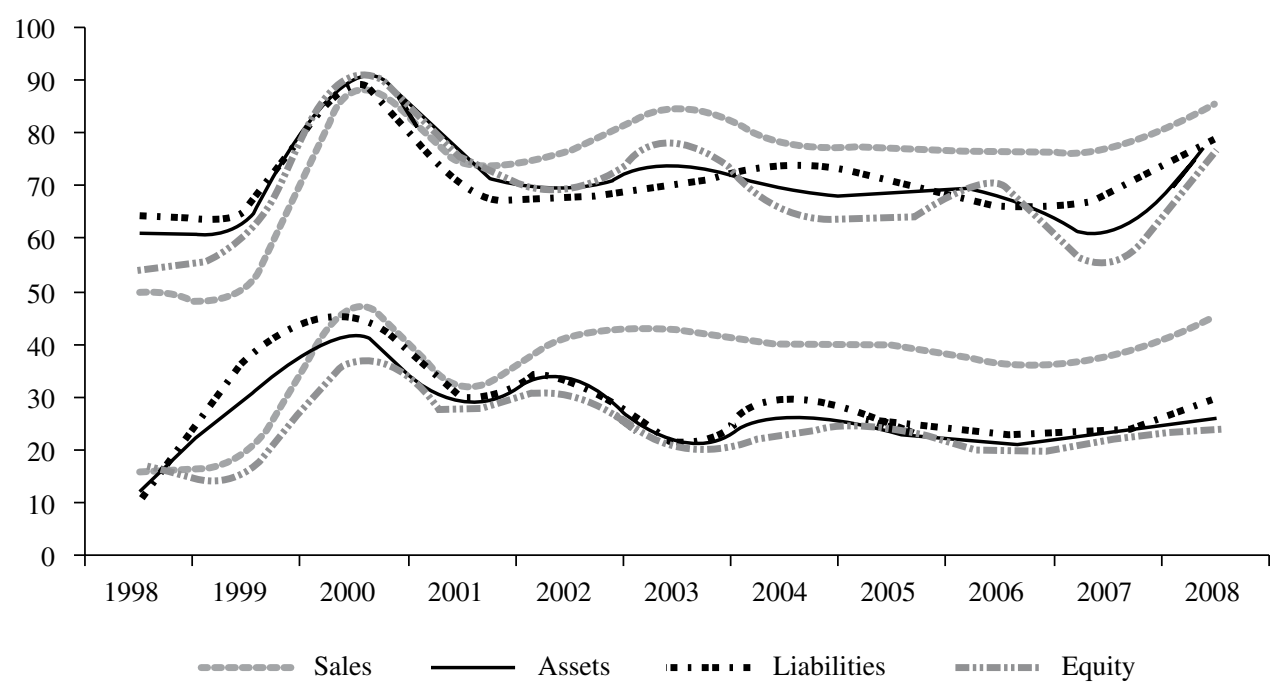

Source: prepared by the author on the basis of data from Peru: The Top 10,000 Companies.

a Only firms with complete data were considered. 
whole, as the top 10 firms account for somewhat over $40 \%$ of sales and just over $20 \%$ of assets, liabilities and equity, while the group of the 100 largest firms accounts for just over $80 \%$ of sales and over $75 \%$ of the other variables analysed. In both subgroups there is a rising trend between 1998 and 2008, although a cyclical pattern can be observed, with peaks in 2000 and 2003 in the case of the subgroup of the country's 100 largest firms.

To analyse the information for all the leading Peruvian firms and by production sector, both traditional financial ratios and some complementary ones have been used. These ratios include, in particular, the sales-to-assets ratio, which is the ratio of sales or total revenue $(T R)$ to assets $(A)$, this being a proxy for the output-to-capital ratio mentioned in the theoretical discussion. Other financial ratios are equity turnover, equating to total revenue $(T R)$ over equity $(C)$. Equity is the sum of capital plus retained earnings. The level of debt is measured as the ratio of total liabilities $(L)$ over total assets $(A)$. Only total liabilities are considered here because there is not enough information available to discriminate between short- and long-term liabilities, or between banking system and non-banking system liabilities. Another indicator is the level of leverage, which expresses the ratio between third-party investments and those made by the partners in a firm: the liabilities-to-equity ratio.

Firms' profitability is measured by four indicators: net after-tax profits relative to sales, which are equivalent to the net return on sales; net profits relative to total assets, which is the return on assets; and net profits relative to equity (return on equity). Because there is a lack of detailed information on costs and spending, whether fixed or variable, the profit margin ${ }^{8}$ is obtained as: $\left[\left(\frac{\text { Sales }}{\text { Expenditure }}\right)-1\right] * 100$

In addition, two investment-related ratios have been considered, investment being understood as the difference between total assets in the current period and the previous one. This investment in current and fixed assets is expressed in relative terms with respect, firstly, to sales or total revenues and, secondly, to net after-tax profits.

Table 4 shows that, taking the whole sample, there has been a relative reduction in levels of indebtedness and leverage among the country's main firms. These were highest at the start of the period and lowest at

8 Expenditure is obtained as the difference of sales minus profits, taking an income tax rate of $30 \%$ for the whole period in question, which is why the profit margin is pre-income tax. the end. The counterpart of lower debt levels was an increase in equity as a share of firms' total assets from $32.92 \%$ to $59.51 \%$. This is important, as it indicates that the growth of firms' total assets has been due more to internally generated resources than to outside resources. Hypotheses explaining this dynamic may be sought both in the behaviour of the banking system and other lenders and in corporate behaviour that became averse to the greater risk involved in growing on the basis of outside financing in response to the external shocks of the Asian crisis and the events of 2001.

All indicators of returns and profit margins show a trajectory similar to the performance of the operating surplus observed in table 1, being lowest at the start of the period and highest towards the end. However, the highest rates of return and margin were obtained in 2006, with lower levels seen in 2007 and 2008. This is because, in accordance with the calculation protocol, all firms not submitting full financial information were removed, and there were more and more of these. The 2006 profit margin was over $30 \%$ of total expenditure and returns on sales exceeded $16 \%$. These results were 2.6 and 2.9 times as great as those of the world's 500 largest companies as reported by Fortune (2011), also for 2006.9

The increased importance of investment selffinancing or internally generated funding in Peruvian firms can also be observed in the financial ratio of investment to net after-tax profits. This is very high at the start of the period, and incorporates the other sources of investment financing other than net after-tax profits, after which it declines. No conclusion can be drawn from the ratio of investment to sales. Another cause reflected in the increase in investment self-financing is the reduced value of equity turnover, which peaked in 1998 before gradually declining and plateauing at between 1.10 and 1.14 from 2002, owing to higher growth in investment by partners in firms (equity).

The sales-to-assets ratio serves to demonstrate how productively assets are used. This encompasses both an adequate performance of the markets that firms' goods and services are sold in and the effectiveness with which assets (both current and fixed) are used to generate greater output and sales. Implicitly, it captures both capital intensity and capital to labour ratios, and also manufacturing processes. Furthermore, according

\footnotetext{
9 The return on sales of the world's 500 largest companies in 2005, 2006, 2007 and 2008 was $6.4 \%, 7.3 \%, 6.7 \%$ and $3.3 \%$, respectively. The profit margin was $10.9 \%, 12.7 \%, 11.6 \%$ and $5.3 \%$, respectively, assuming an average tax rate of $35 \%$.
} 
to equation (8) of the basic model, a rise in this ratio is a counterpart to higher profit margins. The information available shows a series of upward steps as described in the earlier comments. Between 1998 and 1999 it stood at around 0.5. In 2000 it rose to 0.72. Between 2001 and 2003 it was about 0.60 , after which it rose to about 0.62 and 0.66 between 2004 and 2008 .

The table 4 estimates can be calculated for the different sectors of the economy. The analysis goes on to calculate and examine the different correlations between the financial ratios, both for the economy as a whole and for its different sectors. The aim is to assess the scale and sign of the correlations between the different financial ratios hypothesized in the theoretical discussion. For this purpose, use is made of Pearson's correlation coefficient, which measures how two variables move together, irrespective of the units in which the two measurement variables are expressed. The standard formula corresponds to the quotient of the covariance of $x y$ relative to the product of the standard deviations of $x$ and $y: \sigma=\frac{\operatorname{Cov}(x y)}{\sigma_{x} \rho_{y}}$, where the values of the coefficient of correlation must fall between -1 and +1 .

Table 5 shows the matrix of correlations of the aggregate financial ratios for the business sector in the period analysed. The first thing to note is the correlation between the profit margin and the sales-to-assets ratio, which is positive and close to one (1). A higher margin has as its counterpart a higher sales-to-assets ratio, and vice-versa. Second, debt and leverage levels are inversely related with profit margins, to a degree that is significantly different from zero (0). The more debt there

TABLE 4

Peru: main integrated financial ratios in the business sector, 1998-2008

\begin{tabular}{|c|c|c|c|c|c|c|c|c|c|c|c|}
\hline Year & 1998 & 1999 & 2000 & 2001 & 2002 & 2003 & 2004 & 2005 & 2006 & 2007 & 2008 \\
\hline Sales-to-assets ratio & 0.52 & 0.50 & 0.72 & 0.61 & 0.62 & 0.56 & 0.64 & 0.62 & 0.67 & 0.66 & 0.66 \\
\hline Equity turnover & 1.57 & 1.43 & 1.38 & 1.23 & 1.14 & 1.14 & 1.13 & 1.15 & 1.10 & 1.10 & 1.13 \\
\hline Debt level (percentage) & 67.08 & 65.23 & 48.33 & 51.28 & 48.05 & 49.96 & 43.08 & 38.60 & 38.85 & 39.97 & 40.49 \\
\hline Leverage (percentage) & 203.74 & 187.61 & 92.84 & 103.54 & 87.63 & 102.45 & 75.76 & 71.19 & 64.17 & 66.26 & 69.73 \\
\hline Return on sales (percentage) & 0.86 & 2.02 & 8.01 & 3.52 & 6.69 & 4.77 & 10.40 & 13.47 & 16.84 & 16.03 & 13.37 \\
\hline Return on assets (percentage) & 0.45 & 1.00 & 5.75 & 2.14 & 4.18 & 2.66 & 6.66 & 8.42 & 11.20 & 10.62 & 8.76 \\
\hline Return on equity (percentage) & 1.36 & 2.89 & 11.04 & 4.31 & 7.62 & 5.46 & 11.71 & 15.53 & 18.50 & 17.62 & 15.08 \\
\hline Profit margin (percentage) & 1.25 & 2.97 & 12.92 & 5.29 & 10.57 & 7.32 & 17.45 & 23.84 & 31.68 & 29.71 & 23.60 \\
\hline Investment-to-sales ratio (percentage) & - & 4.39 & -334.72 & 60.02 & -22.84 & 24.35 & 24.02 & 37.01 & 25.70 & 13.46 & -11.31 \\
\hline Investment-to-net profits ratio (percentage) & - & $217.31-$ & -4178.771 & 705.98 & -341.39 & 509.99 & 230.96 & 274.71 & 152.63 & 83.94 & -84.61 \\
\hline
\end{tabular}

Source: prepared by the author on the basis of data from Peru: The Top 10,000 Companies.

TABLE 5

Peru: matrix of correlations of integrated financial ratios in the business sector, 1998-2008

\begin{tabular}{|c|c|c|c|c|c|c|c|c|c|c|}
\hline Correlation & $\begin{array}{l}\text { Sales- } \\
\text { to-assets } \\
\text { ratio }\end{array}$ & $\begin{array}{l}\text { Equity } \\
\text { turnover }\end{array}$ & $\begin{array}{l}\text { Debt } \\
\text { level }\end{array}$ & Leverage & $\begin{array}{c}\text { Return } \\
\text { on sales }\end{array}$ & $\begin{array}{l}\text { Return on } \\
\text { assets }\end{array}$ & $\begin{array}{c}\text { Return on } \\
\text { equity }\end{array}$ & $\begin{array}{l}\text { Profit } \\
\text { margin }\end{array}$ & $\begin{array}{l}\text { Investment/ } \\
\text { sales }\end{array}$ & $\begin{array}{l}\text { Investment/ } \\
\text { profit }\end{array}$ \\
\hline Sales-to-assets ratio & 1 & & & & & & & & & \\
\hline Equity turnover & -0.542 & 1 & & & & & & & & \\
\hline Debt level & -0.806 & 0.884 & 1.00 & & & & & & & \\
\hline Leverage & -0.837 & 0.903 & 0.979 & 1.00 & & & & & & \\
\hline Return on sales & 0.731 & -0.731 & -0.907 & -0.825 & 1.00 & & & & & \\
\hline Return on assets & 0.762 & -0.704 & -0.898 & -0.819 & 0.998 & 1.00 & & & & \\
\hline Return on equity & 0.774 & -0.697 & -0.907 & -0.828 & 0.995 & 0.997 & 1.00 & & & \\
\hline Profit margin & 0.702 & -0.709 & -0.883 & -0.793 & 0.998 & 0.996 & 0.990 & 1.00 & & \\
\hline Investment-to sales-ratio & -0.515 & -0.526 & -0.072 & -0.017 & 0.045 & -0.011 & -0.051 & 0.074 & 1.00 & \\
\hline Investment-to-profits ratio & -0.143 & -0.768 & -0.403 & -0.415 & 0.208 & 0.160 & 0.124 & 0.218 & 0.869 & 1.00 \\
\hline
\end{tabular}

Source: prepared by the author on the basis of data from Peru: The Top 10,000 Companies. 
is, the lower profit margins are, and when lower profit margins are observed these correlate with higher levels of indebtedness. Third, the correlation between the salesto-assets ratio and debt and leverage levels is inverse and close to minus one (-1). Fourth, the correlations between investment ratios and profit margins are less conclusive than those just cited. The correlation is close to zero (0) when the investment-to-sales ratio is worked with. It is slightly positive in the case of the correlation between profit margins and the investment-to-profits ratio.

Table 6 shows some of the linear regressions that best explain the profit margin, taking aggregate information at the national level. It is hypothesized, in accordance with equations (8) and (21) of the basic model, that the profit margin is positively correlated with the sales-to-assets ratio, equity, debt-leverage, investment relative to sales, and investment relative to net profits. Five equations are shown that do not reject these relationships, with correlation coefficients and $t$ - and F-tests that are significantly different from zero. ${ }^{10}$ In some of these regressions it has been necessary to use the AR(1) process to correct for the problem of error autocorrelation.

10 With the proviso that the small number of years increases the requirements for the critical values of the $t$ - and F-statistics.
It should be noted here that all the above hypotheses are not included in a single equation, as the relationships of causality hypothesized are not satisfied together. In equation (1), the hypothesis of linkage between the profit margin and sales and equity turnover is not rejected for the linear regressions shown in table 6 . The values of the sales-to-assets ratio parameter are high in this equation, as they are in (2), (3) and (5), with relation to the low value of the equity parameter in all the equations where it appears. The ratio between the profit margin and expenditure shows, as expected, a small but not very significant negative relationship. Lastly, the hypothesis of a positive linkage (albeit one that is weak in accordance with the parameter value) between the profit margin and the investment-to-profits ratio is not rejected in equations (4) and (5). The investment process is accompanied by higher profit margins.

Table 7 shows the sectoral classifier that can be used to rearrange all the company information into 20 production sectors on the basis of the two-digit International Standard Industrial Classification of All Economic Activities (ISIC). ${ }^{11}$ The aim of this regrouping is

11 This reclassification of the ISIC has been carried out for practical reasons, since maintaining the two-digit classification would yield an excessive number of groups for analysis. There would be codes covering very few firms if the traditional classification were kept.

TABLE 6

Peru: linear regressions explaining the profit margin, 1998-2008

\begin{tabular}{|c|c|c|c|c|c|}
\hline \multirow[b]{2}{*}{ Independent variables } & \multicolumn{5}{|c|}{ Profit margin } \\
\hline & Equation 1 & Equation 2 & Equation 3 & Equation 4 & Equation 5 \\
\hline Sales-to-assets ratio & $\begin{array}{l}95.49050 \\
(5.348347)\end{array}$ & $\begin{array}{l}79.09174 \\
(3.86378)\end{array}$ & $\begin{array}{l}46.19334 \\
(1.47320)\end{array}$ & $\begin{array}{l}- \\
-\end{array}$ & - \\
\hline Equity & $\begin{array}{c}0.000223 \\
(5.984843)\end{array}$ & $\begin{array}{c}0.000190 \\
(1.955220)\end{array}$ & $\begin{array}{c}0.000478 \\
(2.235979)\end{array}$ & $\begin{array}{l}- \\
-\end{array}$ & $\begin{array}{c}0.004084 \\
(2.384464)\end{array}$ \\
\hline Investment-to-profits ratio & $\begin{array}{l}- \\
-\end{array}$ & $\begin{array}{l}- \\
-\end{array}$ & $\begin{array}{l}- \\
-\end{array}$ & $\begin{array}{c}0.069022 \\
(15.13292)\end{array}$ & $\begin{array}{c}0.069525 \\
(4.388741)\end{array}$ \\
\hline Expenditure & $\begin{array}{l}- \\
-\end{array}$ & $\begin{array}{l}- \\
-\end{array}$ & $\begin{array}{c}-0.000348 \\
(-1.300289)\end{array}$ & $\begin{array}{l}- \\
-\end{array}$ & $\begin{array}{c}-0.005213 \\
(-2.125269)\end{array}$ \\
\hline $\operatorname{AR}(1)$ & $\begin{array}{l}- \\
-\end{array}$ & $\begin{array}{c}0.587185 \\
(1.090320)\end{array}$ & $\begin{array}{c}0.437123 \\
(1.105957)\end{array}$ & $\begin{array}{c}0.508892 \\
(-1.430741)\end{array}$ & $\begin{array}{c}-0.133368 \\
(-0.338827)\end{array}$ \\
\hline Constant & $\begin{array}{l}-61.26756 \\
(-5.588015)\end{array}$ & $\begin{array}{l}-47.63759 \\
(-2.301315)\end{array}$ & $\begin{array}{l}-23.52326 \\
(-1.000060)\end{array}$ & $\begin{array}{l}-7.25948 \\
(-0.400205)\end{array}$ & $\begin{array}{r}62.17178 \\
1.15956 \\
\end{array}$ \\
\hline Period & $1998-2008$ & $1999-2008$ & 1999-2008 & $2000-2008$ & $2000-2008$ \\
\hline Number of observations & 11 & 10 & 10 & 10 & 10 \\
\hline $\mathrm{R}^{2}$ & 0.906110 & 0.935393 & 0.951187 & 0.963239 & 0.985597 \\
\hline Adjusted R2 & 0.882638 & 0.903089 & 0.912137 & 0.950985 & 0.971193 \\
\hline F-statistic & 38.60305 & 28.95625 & 24.35803 & 78.60843 & 68.42867 \\
\hline Durbin Watson & 0.862099 & 1.610094 & 1.660196 & 1.569452 & 1.793588 \\
\hline
\end{tabular}

Source: prepared by the author on the basis of data from Peru: The Top 10,000 Companies.

Note: $t$-statistic in parentheses. 


\section{Peru: sectoral classifier of information on firms}

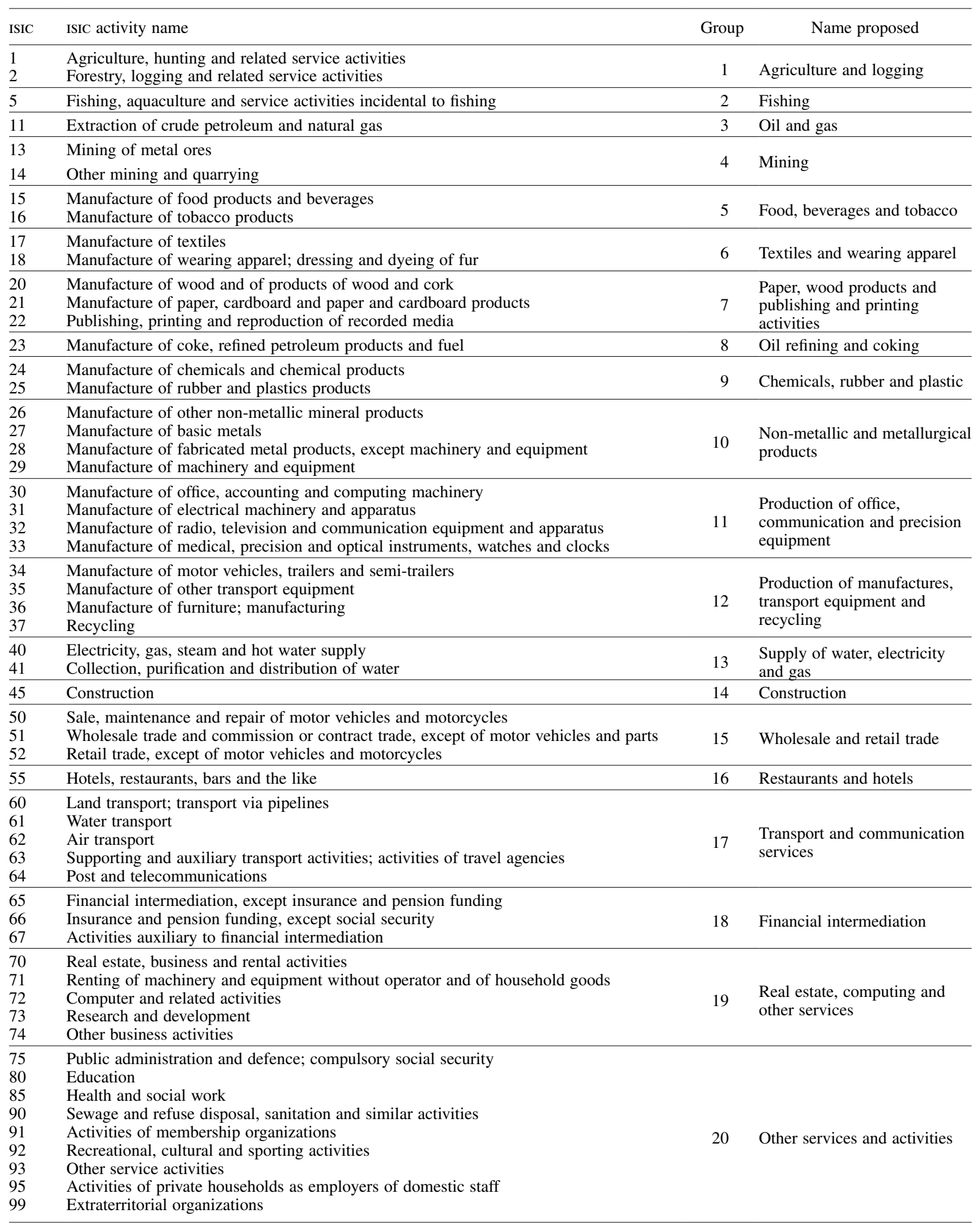

Source: prepared by the author on the basis of the International Standard Industrial Classification of All Economic Activities (ISIC). 
to make it possible to calculate the correlation coefficients of the profit margins for each production sector relative to the other ratios referred to earlier. The agriculture and logging sector, called group 1, encompasses ISIC codes 1 and 2. The fishing, oil and gas, construction and hotels and restaurants sectors continue to stand alone as production sectors, while the rest are regrouped using standard classifications such as mining; food, beverages and tobacco; textiles and wearing apparel; paper, wood and printing; oil refining and coke production; chemicals, plastics and rubber; non-metallic and metallurgical products; production of office, communication and precision equipment; production of transport and manufacturing equipment; supply of water, electricity and gas; construction; wholesale and retail commerce; transport and communication services; financial intermediation; real estate activities and computing services; and other services and activities.

Table 8 shows some correlations between profit margins and four sets of financial variables for the main production sectors. It also presents the aggregate results for all firms and the percentage correspondence of sectoral results with the total. In the first place, with a correspondence of $95 \%$ between the sectoral and aggregate results, comes the inverse relationship between profit margins and levels of debt and leverage. The sign of this relationship holds for all production sectors, with the exception of a positive correlation in sector 19 (real estate activities and computing services). Here, higher profit margins are accompanied by higher levels of debt and vice-versa. The correlation is negative but below -0.5 in the cases of fishing; paper, wood and printing; and production of transport and manufacturing equipment.

The positive correlation between profit margins and the sales-to-assets ratio at the aggregate level is replicated in $65 \%$ of production sectors, the exceptions being agriculture; oil and gas; oil refining and coking; restaurants and hotels; transport and communication services; financial intermediation; and other services and activities. The inverse relationship between profit margins and equity turnover is found in $70 \%$ of production sectors, the exceptions being fishing; mining; nonmetallic and metallurgical products; production of office, communication and precision equipment; production of

TABLE 8

Peru: some profit margin correlations for the whole economy and the main production sectors

\begin{tabular}{|c|c|c|c|c|c|c|c|}
\hline \multirow[b]{2}{*}{ Sector } & \multicolumn{2}{|c|}{ Growth } & \multicolumn{2}{|c|}{ Debt } & \multicolumn{2}{|c|}{ Investment } & \multirow[b]{2}{*}{$\begin{array}{l}\text { Sales and } \\
\text { debt }\end{array}$} \\
\hline & $\begin{array}{l}\text { Sales-to- } \\
\text { assets ratio }\end{array}$ & $\begin{array}{l}\text { Equity } \\
\text { turnover }\end{array}$ & Debt level & Leverage & $\begin{array}{l}\text { Investment- } \\
\text { to-sales ratio }\end{array}$ & $\begin{array}{l}\text { Investment- } \\
\text { to-net profits } \\
\text { ratio }\end{array}$ & \\
\hline Total & 0.702 & -0.709 & -0.883 & -0.793 & 0.074 & 0.218 & -0.806 \\
\hline 1 & -0.379 & -0.580 & -0.579 & -0.598 & -0.044 & -0.299 & 0.391 \\
\hline 2 & 0.504 & 0.070 & -0.188 & -0.145 & 0.210 & 0.242 & -0.132 \\
\hline 3 & -0.662 & -0.533 & -0.513 & -0.534 & 0.115 & 0.112 & 0.553 \\
\hline 4 & 0.939 & 0.912 & -0.860 & -0.831 & -0.263 & -0.440 & -0.857 \\
\hline 5 & 0.220 & -0.553 & -0.627 & -0.932 & -0.202 & -0.456 & 0.507 \\
\hline 6 & 0.178 & -0.690 & -0.687 & -0.628 & 0.517 & 0.184 & -0.608 \\
\hline 7 & 0.336 & -0.115 & -0.310 & -0.394 & 0.242 & 0.213 & -0.712 \\
\hline 8 & -0.522 & -0.746 & -0.503 & -0.579 & 0.402 & -0.011 & -0.001 \\
\hline 9 & 0.399 & -0.096 & -0.517 & -0.556 & -0.251 & -0.038 & -0.592 \\
\hline 10 & 0.373 & 0.077 & -0.687 & -0.668 & 0.182 & 0.927 & -0.135 \\
\hline 11 & 0.834 & 0.699 & -0.661 & -0.525 & 0.229 & -0.054 & -0.440 \\
\hline 12 & 0.392 & 0.121 & -0.072 & -0.043 & -0.086 & -0.371 & 0.112 \\
\hline 13 & 0.087 & -0.232 & -0.568 & -0.581 & 0.384 & 0.136 & 0.502 \\
\hline 14 & 0.569 & -0.308 & -0.453 & -0.600 & -0.108 & 0.165 & 0.010 \\
\hline 15 & 0.549 & -0.352 & -0.661 & -0.382 & 0.434 & -0.324 & -0.757 \\
\hline 16 & -0.628 & -0.792 & -0.416 & -0.522 & 0.088 & 0.333 & 0.051 \\
\hline 17 & -0.134 & -0.257 & -0.469 & -0.468 & 0.478 & 0.283 & 0.437 \\
\hline 18 & -0.298 & -0.486 & -0.611 & -0.522 & -0.397 & 0.388 & 0.151 \\
\hline 19 & 0.456 & 0.238 & 0.220 & 0.141 & 0.441 & 0.429 & -0.205 \\
\hline 20 & -0.671 & -0.587 & -0.574 & -0.525 & 0.124 & 0.023 & 0.916 \\
\hline $\begin{array}{l}\text { Correspondence with } \\
\text { the total (percentage) }\end{array}$ & 65.0 & 70.0 & 95.0 & 95.0 & 65.0 & 60.0 & 50.0 \\
\hline
\end{tabular}

Source: prepared by the author on the basis of data from Peru: The Top 10,000 Companies. 
transport and manufacturing equipment; and real estate activities and computing services.

The correspondence between the aggregate and sectoral correlations for the sales-to-assets ratio and debt levels and the correspondence between margins and investment stand at between 50\% and 65\%. Higher profit margins are associated with higher investment levels and vice-versa. The link is positive and strongest in the case of the investment-to-profits ratio for fishing; paper, wood and printing; non-metallic and metallurgical products; hotels and restaurants; transport and communication services; financial intermediation; and real estate activities and computing services. The relationship is negative and considerably different from zero (0) in the cases of agriculture; mining; food, beverages and tobacco; and production of transport and manufacturing equipment.

These 20 sectors were subsequently classified using the traditional division into non-durable consumer goods, intermediate goods and capital and consumer durable goods. It was established that agriculture and logging; fishing; food, beverages and tobacco; textiles and wearing apparel; paper, wood and printing; supply of water, electricity and gas; wholesale and retail commerce; restaurants and hotels; transport and communication services; and other services and activities formed part of the non-durable consumer goods sector. Oil and gas; mining; oil refining and coke production; chemicals, rubber and plastic; financial intermediation; and real estate and computing services classified in the intermediate goods group. The capital and consumer durable goods group contained non-metallic and metallurgical products; production of office and communication equipment; production of transport and manufacturing equipment; and construction.

Table 9 shows the reclassification of all the firms in the sample on the basis of the traditional criteria. The results match the sectoral results discussed earlier. There is complete correspondence between the aggregate result and that of the relevant subsectors when it comes to the link between profit margins and debt and leverage levels. This correlation is negative. A negative correlation coefficient is maintained between profit margins and equity turnover. The correspondence is less when it comes to the link between profit margins and the sales-to-assets ratio and between profit margins and investment relative to earnings. Lastly, as in table 8, the correspondence is less in the case of the correlation between profit margins and the investment-to-sales ratio and the link between sales and debt.

TABLE 9

Peru: some profit margin correlations for the whole economy, consumer goods, intermediate goods and capital and non-durable consumer goods

\begin{tabular}{|c|c|c|c|c|c|c|c|}
\hline \multirow[b]{2}{*}{ Sector } & \multicolumn{2}{|c|}{ Growth } & \multicolumn{2}{|c|}{ Debt } & \multicolumn{2}{|c|}{ Investment } & \multirow[b]{2}{*}{$\begin{array}{c}\text { Sales and } \\
\text { debt }\end{array}$} \\
\hline & $\begin{array}{l}\text { Sales-to- } \\
\text { assets ratio }\end{array}$ & $\begin{array}{l}\text { Equity } \\
\text { turnover }\end{array}$ & Debt level & Leverage & $\begin{array}{l}\text { Investment- } \\
\text { to-sales ratio }\end{array}$ & $\begin{array}{l}\text { Investment- } \\
\text { to-net profits } \\
\text { ratio }\end{array}$ & \\
\hline Total & 0.702 & -0.709 & -0.883 & -0.793 & 0.074 & 0.218 & -0.806 \\
\hline Consumer goods & -0.748 & -0.822 & -0.746 & -0.804 & -0.315 & -0.265 & 0.826 \\
\hline Intermediate goods & 0.548 & -0.203 & -0.697 & -0.593 & 0.258 & 0.199 & -0.915 \\
\hline Capital goods & 0.361 & -0.064 & -0.787 & -0.799 & -0.069 & 0.755 & 0.069 \\
\hline $\begin{array}{l}\text { Correspondence with } \\
\text { total (percentage) }\end{array}$ & 66.7 & 100.0 & 100.0 & 100.0 & 33.3 & 66.7 & 33.3 \\
\hline
\end{tabular}

Source: prepared by the author on the basis of data from Peru: The Top 10,000 Companies. 


\section{V}

\section{Final considerations}

In the post-Keynesian school, the level of and changes in the profit margins of fixed-price sectors are held to depend on a set of factors such as the price elasticity of demand, the behaviour and reactions of possible entrants into the industry and the minimization of possible regulatory reactions by the authorities. Also important are the industry's growth rate and the outputto-capital ratio, which are the counterpart of any firm's investment decisions. Profit margins rise when these last variables grow more strongly, owing to investment self-financing needs.

These theories seem to be helpful in explaining the behaviour of profit margins, investment and financing in the Peruvian business sector between 1998 and 2008. There are a number of grey areas, however, owing both to the lack of detailed statistical information and to the need for a supplementary theoretical framework to account for the evolution of profit margins in production sectors other than manufacturing. The lack of longer time series and more detailed information limits the scope for analysis. The greatest limitation of the aggregate information concerns the use of the operating surplus variable, as unfortunately this aggregates the rents and income of self-employed people in urban and rural areas with company profits. It is essential for specific information to be presented for each sector.

The GDP share of the operating surplus has grown over time, and within this the greatest contribution has been made by commerce and services, although the mining sector and hydrocarbons have increased their contribution to the surplus because of their greater dynamism and high international prices. Electricity, water and construction have also registered a growing contribution to the operating surplus, although the growth of these profit margins would seem to be due to the same factors as have operated in manufacturing.

Information from firms is useful for the analysis because it allows basic financial ratios to be estimated at both the aggregate and sectoral levels. When the representativeness of the sample is compared with the national total, furthermore, it transpires that these are adequately representative of the aggregate for the period under analysis. Because a ranking of the country's largest firms is used, however, smaller businesses are omitted, as are those operating in sectors dominated by what are probably the most competitive smaller production units. The aggregate analysis does not determine high levels of concentration, but when it is carried out for the 10 and 100 largest firms in the annual surveys, these subgroups of firms account for a substantial proportion of net profits, liabilities, assets, sales and equity.

The evolution of profit margins and of all the profitability indicators estimated on the basis of the sample of firms analysed displays a rising trajectory similar to that of the operating surplus. This correspondence was less in 2007 and 2008, however, owing to the fall-off in reporting of after-tax earnings by private firms. In 2006, profit margins and after-tax profits relative to net sales were equivalent to 2.6 and 2.9 times the same ratios, respectively, for the world's 500 largest firms as reported by Fortune magazine.

The aggregate information shows that there has been a relative reduction in debt and leverage levels in the Peruvian business sector. The counterpart of these lower debt levels has been an increase in the share of equity in total corporate assets. Unfortunately, there is not the information available to ascertain whether this reduction in the debt level was due to the behaviour of the banking system and other lenders or to corporate behaviour that became adverse to the greater risk involved in growing on the basis of outside financing in response to the external shock of the Asian crisis and the events in the international economy in 2001.

At the level of both the aggregate sample and the sectoral subgroups, what stands out is the positive correlation of close to one (1) between profit margins and the sales-to-assets ratio. A higher margin is matched by a higher sales-to-assets ratio (a proxy for the output-tocapital ratio) and vice-versa. Second, debt and leverage maintained a relationship with profit margins that was inverse and significantly different from zero $(0)$. The higher the debt, the lower the profit margins, and when lower profit margins are observed these correlate with higher levels of debt. Third, the correlation between the salesto-assets ratio and debt and leverage levels is inverse and close to minus one (-1). Fourth, the correlations between investment ratios and profit margins are less conclusive than the previous ones, although they are positive in the case of the correlation between profit margins and the investment-to-profits ratio. The investment process is 
accompanied by higher profit margins. Peruvian firms tend to self-finance their investment decisions. The two decision-making processes are linked.

The lesser correlation of profit margins and investment relative to sales would seem to demonstrate, at the microeconomic level, that higher profit margins can be generated without the need for higher investment. Higher margins may simply be the result of a policy designed to obtain greater returns on investment or higher dividends. This is a subject that ought to be incorporated into theories for determining profit margins. The factors underlying today's lower borrowing also need to be explored in more detail, as does the question of whether or not investment self-financing is related in some way to the behaviour of the financial sector.

(Original: Spanish)

\section{Bibliography}

Alarco, G. (2010a), "Growth and concentration among the leading business groups in Mexico", CEPAL Review, No. 101 (LC/ G.2455-P), Santiago, Chile, August.

(2010b), "Crisis financiera internacional y patrón de crecimiento de una economía mediana y dependiente: el caso del Perú", Convergencia, vol. 17, No. 54, Mexico City, Autonomous University of Mexico State, SeptemberDecember.

Eichner, A. (1988), "Una teoría de la determinación del margen de ganancia en el oligopolio", Economía postkeynesiana, J. Ocampo (ed.), Mexico City, Fondo de Cultura Económica.

Feiwel, G. (1981), Michal Kalecki: contribuciones a la teoría de la política económica, Mexico City, Fondo de Cultura Económica.

Fortune (2011), "Global 500 annual ranking of the world's largest corporations" [online] http://money.cnn.com/magazines/ fortune/global500/2010/index.html.

Harcourt, C. and P. Kenyon (1988), "La fijación de precios y la decisión de inversión", Economía postkeynesiana, J.A. Ocampo (ed.), Mexico City, Fondo de Cultura Económica.

INEI (National Institute of Statistics and Informatics) (2011), "Sistema de información económica" [online] http://www.inei.gob.pe/ web/aplicaciones/siemweb/index.asp?id=003

Kalecki, M. (1954), Theory of Economic Dynamics, London, George Allen and Unwin.

Lindenboim, J. (2008), "Distribución funcional del ingreso, un tema olvidado que reclama atención”, Problemas del desarrollo, vol. 39, No. 153, Mexico City, Institute of Economics Research, National Autonomous University of Mexico, April.

Ocampo, J. (1988), "De Keynes al análisis postkeynesiano", Economía postkeynesiana, J.A. Ocampo (ed.), Mexico City, Fondo de Cultura Económica.

Peru Top Publications (2010), Peru: The Top 10,000 Companies [online] http://www.perutop10000.com.pe/.

(2008), Peru: The Top 10,000 Companies [online] http:// www.perutop10000.com.pe/.
(2007), Peru: The Top 10,000 Companies [online] http:// www.perutop10000.com.pe/.

(2006), Peru: The Top 10,000 Companies [online] http:// www.perutop10000.com.pe/.

(2005), Peru: The Top 10,000 Companies [online] http:// www.perutop10000.com.pe/. (2005).

(2004), Peru: The Top 10,000 Companies [online] http:// www.perutop10000.com.pe/.

(2002), Peru: The Top 10,000 Companies [online] http:// www.perutop10000.com.pe/.

(2001), Peru: The Top 10,000 Companies [online] http:// www.perutop10000.com.pe/.

Steindl, J. (1988), "Precios, costos y márgenes de ganancia", Economía postkeynesiana, J.A. Ocampo (ed.), Mexico City, Fondo de Cultura Económica.

Sylos Labini, P. (1969), Oligopoly and Technical Progress, Cambridge, MA, Harvard University Press.

Taylor, L. (1986), Modelos macroeconómicos para los países en desarrollo, Mexico City, Fondo de Cultura Económica.

United Nations (2002), International Standard Industrial Classification of All Economic Activities (ISIC). Revision 3.1 (ST/ESA/STAT/ SER.M/4/Rev.3.1), New York [online] http://documents-ddsny.un.org/doc/UNDOC/GEN/N02/764/15/pdf/N0276415. pdf?OpenElement.

Urzúa, C. (2009), "Efectos sobre el bienestar social de las empresas con poder de mercado en México", Finanzas públicas, vol. 1, No. 1, Mexico City, Centro de Estudios de las Finanzas Públicas.

Vargas, G. (2007), "La nueva microeconomía dinámica", Investigación económica, vol. 66, No. 162, Mexico City, National Autonomous University of Mexico.

Wood, A. (1988), "El margen de ganancia a largo plazo", Economía postkeynesiana, J.A. Ocampo (ed.), Mexico City, Fondo de Cultura Económica. 